\title{
NURSING PROGRAM
}

Thursday, June 4

\begin{tabular}{|c|c|c|}
\hline & Session 1 - Keynote Address & Hall 3 \\
\hline & Chair: Auður Ketilsdóttir, (IS) and Tone M. Norekval, (NO) & \\
\hline 08:30-08:40 & Opening Remarks & \\
\hline 08:40-09:40 & $\begin{array}{l}\text { Inflammation and Coagulation in Acute Coronary Syndromes } \\
\text { Nancy Munro (USA) }\end{array}$ & \\
\hline \multirow[t]{3}{*}{ 09:45-10:00 } & Discussion & \\
\hline & Session 2 - Resuscitation- Patient and Practice & \\
\hline & Chair: Hallveig Broddadóttir (IS) and Mona Schlyter (SE) & \\
\hline 10:30-10:50 & $\begin{array}{l}\text { Bystander CPR - With or without ventilation? } \\
\text { Katarina Bohm, Stockholm (SE) }\end{array}$ & \\
\hline $10: 50-11: 10$ & $\begin{array}{l}\text { Resuscitation - Nursing skills } \\
\text { Hildigunnur Svavadóttir (IS) }\end{array}$ & \\
\hline $11: 10-11: 30$ & $\begin{array}{l}\text { Preventing cardiac arrest. Nurses role } \\
\text { Bylgja Kærnested (IS) }\end{array}$ & \\
\hline 11:30-11:50 & $\begin{array}{l}\text { Experiences following sudden cardiac arrest and resuscitation } \\
\text { Auður Ketilsdóttir (IS) }\end{array}$ & \\
\hline
\end{tabular}

Chair: Elsebeth Lang (DK) Anna G. Gunnarsdóttir (IS)

13:00-13:20 How do spouses interpret the cardiac arrest situation and how do they intervene? Ann-Britt Thorén, (SE)

13:20-13:40 Family presence during CPR Tone M. Norekval (NO)

13:40-14:00 To be with a cold body; family presence during hypothermia treatment Marianne S. Holm (NO)

14:00-14:20 The experience of ICD storm Pernille Andersen (DK)

\section{5:00-16:20 Session 4 - Oral Abstract Session - Educational Issues}

Chair: Bylgja Kærnested (IS) and Auður Ketilsdóttir (IS)

15:05-15:20 NP 0-1 European cardiovascular nurses and allied professions' practical skills in cardiopulmonary resuscitation Åsa Axelsson (SE), AB Thorén (SE), S Aune (SE), B Fridlund (SE), P Moons (BE), J Mårtensson (SE), K Smith (UK), A Strömberg (SE), DR Thompson (UK), TM Norekvål (NO)

15:20-15:35 NP O-2 Education in cardiopulmonary resuscitation in Sweden and its clinical consequences Anneli Strömsöe, Johan Herlitz, Åsa Axelsson, Leif Svensson, Katarina Göransson, Birgitta Andersson, Stig Holmberg, (SE) 
15:35-15:50 NP 0-3 Cognitive recovery after sudden cardiac arrest: a wake-up call for survivors and health care providers

Hildur Rut Albertsdóttir, Auður Ketilsdóttir, Helga Jónsdóttir (IS)

15:50-16:05 NP 0-4 Evaluation of information given to patients affected by acute coronary syndrome transferred between hospitals by air ambulance

Siv Reidun Osdal, Solrun Osdal, Johan Barstad, Roar Stokken, Torstein Hole, (NO)

16:05-16:20 NP 0-5 Patient education in a representative sample of patients having elective cardiac surgery in Iceland

Heiða S. Ólafsdóttir, Brynja Ingadottir, Herdís Sveinsdóttir, (IS)

Friday, June 5

\begin{tabular}{|c|c|c|}
\hline & Session 5 - Pre-per-post Cardiac Surgery: How Can Nurses Contribute? & Hall 3 \\
\hline & Chair: Nina Falun (NO) Auður Ketilsdóttir (IS) & \\
\hline $8: 30-9: 10$ & $\begin{array}{l}\text { Cardiac tamponade } \\
\text { Nancy Munro (USA) }\end{array}$ & \\
\hline 9:10-9:30 & $\begin{array}{l}\text { Wound infections following saphenectomy in coronary artery bypass surgery } \\
\text { Helga Hallgrímsdóttir (IS) }\end{array}$ & \\
\hline $9: 30-9: 50$ & $\begin{array}{l}\text { On-pump or off-pump; patient reported outcomes } \\
\text { Lars Mathiesen (NO) }\end{array}$ & \\
\hline \multirow[t]{3}{*}{ 9:50-10:10 } & $\begin{array}{l}\text { Patient education - Pre and post CABG } \\
\text { Brynja Ingadóttir (IS) }\end{array}$ & \\
\hline & Session 6 - Prevention and rehabilitation - Follow up & \\
\hline & Chair: Teija Korpilahti (FN) Anna G. Gunnarsdóttir (IS) & \\
\hline 10:30-10:50 & $\begin{array}{l}\text { ICD recipients' experience of living with an ICD } \\
\text { Ingvild Morken (NO) }\end{array}$ & \\
\hline 10:50-11:10 & $\begin{array}{l}\text { Living with an ICD recipient } \\
\text { Anne Birgitte Vogelsang. (DK) }\end{array}$ & \\
\hline 11:10-11:30 & $\begin{array}{l}\text { Follow-up care for IHD patients } \\
\text { Inga Valborg Ólafsdóttir (IS) }\end{array}$ & \\
\hline 11:30-11:50 & $\begin{array}{l}\text { Designed exercise recommendation to different heart disease patient and evaluation of } \\
\text { execution ability } \\
\text { Riitta-Liisa Hasu (FN) }\end{array}$ & \\
\hline
\end{tabular}

Session 7 - Oral abstract session - Living with heart disease

Chair: Bylgja Kærnested (IS) and Auður Ketilsdóttir (IS)

13:00-13:15 NP 0-6 Health-related quality of life in women with coronary artery disease Hallveig Broddadóttir (IS), Louise Jensen (CA), Colleen Norris (CA), Michelle Graham (CA)

13:15-13:30 NP 0-7 Determinants of quality of life in older female acute myocardial infarction survivors Tone M Norekvål (NO), Bengt Fridlund (SE), Philip Moons (BE), Jan E Nordrehaug (NO), Tore Wentzel-Larsen (NO), Berit Rokne (NO) 
13:30-13:45 NP 0-8 Diabetes and type d personality predict chronic anxiety in cardioverter-defibrillator patients: a multi-center study

Agnes Muskens-Heenskerk, Krista Van den Broek, Dominic Theuns, Marco Alings, Albert Meijer, Luc Jordaens, Johan Denollet, Susanne Pedersen, (NL)

13:45-14:00 NP 0-9 Beliefs about prescribed medicines associated to treatment in patients with cardiovascular disease

Mona From Attebring (SE)

14:00-14:15 NP 0-10 Heart failure management programs in Finland Sirkka Ekola, Maija Hupli, (FI)

15:00- 15:30 Concluding Remarks 